University of Nebraska - Lincoln

DigitalCommons@University of Nebraska - Lincoln

Publications from USDA-ARS / UNL Faculty

U.S. Department of Agriculture: Agricultural

Research Service, Lincoln, Nebraska

10-19-2005

\title{
Corn Stalk Nitrate Concentration Profile
}

Wally Wilhelm

University of Nebraska-Lincoln, wally.wilhelm@ars.usda.gov

Gary E. Varvel

University of Nebraska-Lincoln, gevarvel@windstream.net

James S. Schepers

University of Nebraska-Lincoln, james.schepers@gmail.com

Follow this and additional works at: https://digitalcommons.unl.edu/usdaarsfacpub

Part of the Agricultural Science Commons

Wilhelm, Wally; Varvel, Gary E.; and Schepers, James S., "Corn Stalk Nitrate Concentration Profile" (2005). Publications from USDA-ARS / UNL Faculty. 67.

https://digitalcommons.unl.edu/usdaarsfacpub/67

This Article is brought to you for free and open access by the U.S. Department of Agriculture: Agricultural Research Service, Lincoln, Nebraska at DigitalCommons@University of Nebraska - Lincoln. It has been accepted for inclusion in Publications from USDA-ARS / UNL Faculty by an authorized administrator of DigitalCommons@University of Nebraska - Lincoln. 


\title{
Corn Stalk Nitrate Concentration Profile
}

\author{
W. W. Wilhelm,* G. E. Varvel, and J. S. Schepers
}

\begin{abstract}
The end-of-season stalk nitrate test provides a method of assessing the $\mathbf{N}$ available to the corn (Zea mays $\mathbf{L}$.) crop during the latter part of the season. This study was conducted to determine how stalk nitrate test results and interpretations are affected by sample composition. Stalks were collected from three field sites and separated into phytomers (node plus internode above), which were subdivided into three or five segments after length was measured. Nitrate- $\mathrm{N}$ concentration of phytomers decreased linearly from the soil to the ear. Within a phytomer, segments also decreased acropetally (from base to apex). Node tissue $\mathrm{NO}_{3}-\mathrm{N}$ concentration did not differ from that of the internode segment immediately above the node. Weighted means were used to compute $\mathrm{NO}_{3}-\mathrm{N}$ concentration of stalk samples collected $5 \mathrm{~cm}$ higher (from 20 to $40 \mathrm{~cm}$ above the soil) or lower (from 10 to $30 \mathrm{~cm}$ above the soil) on the stalk than in the original method (from 15 to $35 \mathrm{~cm}$ above the soil). Although the three samples (10-30, 15-35, and $20-40 \mathrm{~cm}$ ) differed in $\mathrm{NO}_{3}-\mathrm{N}$ concentration, the difference was only about $15 \%$ compared with the $25 \%$ difference in sampling position ( $\pm 5 \mathrm{~cm}$ of $20-\mathrm{cm}$ sample length). The phytomer nearest the soil had 35 to $40 \%$ greater $\mathrm{NO}_{3}-\mathrm{N}$ concentrations than the section of stalk 15 to $35 \mathrm{~cm}$ above the soil. Critical values delineating yield-limiting, adequate, and excessive $N$ availability should be modified if stalk sections other than the standard 15 to $35 \mathrm{~cm}$ section are used. However, the qualitative nature of the stalk nitrate test and the range of $\mathrm{NO}_{3}-\mathrm{N}$ concentrations observed with reasonable corn cultural practices $(1000 \times)$ make this test quite robust and precise definition of sample composition and critical values less necessary.
\end{abstract}

$T$ HE END-OF-SEASON corn stalk nitrate test (hereafter referred to as the stalk nitrate test) was proposed and advocated by Binford et al. (1990) as a method of determining if excessive or insufficient $\mathrm{N}$ was available to the corn crop during the latter part of the season. In the test, $20-\mathrm{cm}$ segments of corn stalks (between 15 and $35 \mathrm{~cm}$ above the soil) are collected from several plants $(\sim 10)$, dried, ground, and analyzed for nitrate-N. Nitrate-N concentrations $<700 \mathrm{mg} \mathrm{kg}^{-1}$ plant tissue indicate that available $\mathrm{N}$ limited grain yield; whereas, nitrate- $\mathrm{N}$ concentrations $>2000 \mathrm{mg} \mathrm{kg}^{-1}$ indicate excessive amounts of $\mathrm{N}$ were available to the crop (Binford et al., 1992). Other researchers have evaluated the proposed test and concur that when stalk nitrate concentrations are great $(>2000 \mathrm{mg}$ $\mathrm{kg}^{-1}$ ), excessive levels of $\mathrm{N}$ were available to the crop (Varvel et al., 1997). These studies suggest that the stalk nitrate test can be used as a postmortem to determine if yield-limiting or excessive $\mathrm{N}$ were present. Historical

USDA-ARS, 120 Keim Hall, Univ. of Nebraska, Lincoln, NE 685830934. This paper is a joint contribution of the USDA's Agricultural Research Service and the Agricultural Research Division of the Univ. of Nebraska. Published as Journal Series no. 14914. Received 21 Mar. 2005.*Corresponding author (wwilhelm1@unl.edu).

Published in Agron. J. 97:1502-1507 (2005).

Nitrogen Management

doi:10.2134/agronj2005.0085

(C) American Society of Agronomy

677 S. Segoe Rd., Madison, WI 53711 USA knowledge of crop $\mathrm{N}$ need may be used by producers to guide future fertilizer-N management thereby improving profitability and reducing environmental degradation.

To be a useful crop management tool, methods for collecting and analyzing samples must be straightforward and reasonably flexible so producers and consultants can adapt to field conditions as they gather samples. It is unrealistic to assume that samples will always be exactly $20-\mathrm{cm}$ long and can always be collected between 15 and $35 \mathrm{~cm}$ above the ground under field situations. For example, if samples are collected after combine harvest, the specified stalk segment (Binford et al., 1990) may be destroyed or severely damaged and therefore inappropriate for use in assessing late-season $\mathrm{N}$ nutrition of the crop. The objective of this study was to determine the distribution of nitrate by phytomer (node and the internode above) within stalks of corn and how stalk nitrate test results and interpretations would be affected if samples were collected from a portion of the stalk different from that specified in the original method (Binford et al., 1990).

\section{MATERIALS AND METHODS}

At physiological maturity, stalks were collected from 20 corn plants grown in a rainfed, general production field at the Agronomy Havelock Farm, Lincoln, NE, to conduct initial analyses (designated the 20-stalk experiment in the remainder of the paper). NC+ hybrid 4880 was planted in late April at about 49000 plants ha ${ }^{-1}$. Nitrogen was applied pre-plant at $140 \mathrm{~kg} \mathrm{ha}^{-1}$ as anhydrous ammonia. Weeds were controlled by a combination of pre-emergence herbicides and cultivation. Crop yield was $6.35 \mathrm{Mg} \mathrm{ha}^{-1}$. Stalks were randomly assigned to 1 of 10 replications. Leaves were removed and stalks airdried before processing. During processing, stalks were cut immediately below each node. Each phytomer was further divided into six pieces: the node and five equal-length pieces of each internode. Comparable components (i.e., node from the first phytomer above the soil or the third internode segment of the second phytomer down from the ear) from the two stalks in each replication were combined and ground with a Wiley mill ${ }^{1}$ (Thomas-Wiley Co., Philadelphia, PA) to pass a 2-mm screen. Nitrate was extracted and analyzed with a nitrate electrode (Wilhelm et al., 2000).

Corn stalks were collected from two experiments including continuous corn and corn-soybean [Glycine $\max (\mathrm{L}$.$) Merr.]$ cropping systems and $\mathrm{N}$ rates as treatments. The first experiment was irrigated (designated the irrigated experiment in the remainder of this paper) and established near Shelton, NE, on a Hord silt loam (fine-silty, mixed, mesic, Pachic Haplustoll). The experiment was part of the research component of

${ }^{1}$ Mention of products and equipment are for information only and do not imply endorsement of products by the authors, USDA-ARS, or University of Nebraska, Agricultural Research Division.

Abbreviations: E-1, first phytomer below the ear node; E-2, second phytomer below the ear node; $\mathrm{S}+1$, first phytomer above the soil; $\mathrm{S}+2$, second phytomer above the soil. 
the Nebraska Management System Evaluation Area (MSEA) project to develop crop and soil management practices that reduce nitrate contamination of groundwater. The study was designed with four randomized complete blocks. Treatments were applied in a split-split-split plot arrangement. Treatment factors included cropping system (whole plot), corn hybrid (subplot), and $\mathrm{N}$ fertilizer application rate (sub-subplot). Subsubplots were $15.2 \mathrm{~m}$ long by $7.2 \mathrm{~m}$ (eight rows) wide. Details of the experimental design and crop management practices were presented by Varvel et al. (1997). For the current study the continuous corn and corn-soybean rotations, the Pioneer brand hybrids ' 3162 ' and ' 3417 ', and the 0,100 , and $200 \mathrm{~kg} \mathrm{~N}$ $\mathrm{ha}^{-1}$ treatments were sampled. Corn was seeded in late April in $91-\mathrm{cm}$ rows at 71600 seeds $\mathrm{ha}^{-1}$. Liquid urea-ammonium nitrate solution $(28-0-0)$ was applied with the seed at the rate of $11 \mathrm{~kg} \mathrm{~N} \mathrm{ha}^{-1}$. Nitrogen treatments were applied by broadcasting granular ammonium nitrate $(34-0-0)$ in early June.

The second experiment was rainfed (designated as the dryland experiment in the remainder of this paper) and was located on the Agronomy Farm at the University of Nebraska Agricultural Research and Development Center near Mead, NE, on a well-drained Sharpsburg silty clay loam (fine, smectitic, mesic Typic Argiudoll). Seven cropping systems (three monocultures, two 2-yr rotations, and two 4-yr rotations) with three rates of $\mathrm{N}$ fertilizer were included in the entire experiment. For this study, only the continuous corn and cornsoybean cropping systems were used. Cropping system treatments were assigned to 9 by $32 \mathrm{~m}$ experimental units in five randomized complete blocks. Three subplots $(9$ by $10 \mathrm{~m})$, separated by $1-\mathrm{m}$ alleys, were randomly assigned $\mathrm{N}$ rates of 0,90 , or $180 \mathrm{~kg} \mathrm{~N} \mathrm{ha}^{-1}$. Nitrogen was broadcast as ammonium nitrate in early June. The Pioneer brand hybrid ' 3162 ' was planted in early May at 47000 seed ha ${ }^{-1}$ in $76-\mathrm{cm}$ rows.

At both sites, cultural practices were similar to those used by local producers. Previous crop residue was shredded in late November. All plots were tilled with a tandem disk before planting. Weeds were controlled using combinations of preemergence herbicides, cultivation, and hand weeding.

Ten plants were collected after physiological maturity, but before combine harvest, from the treatment combinations used in this study from each block in both experiments. Plants were cut at the soil surface and again above the primary ear node. Leaves were removed. Stalks were bundled, labeled, and air-dried before processing.

During processing in preparation for nitrate analysis, the number of phytomers was recorded. Stalks were separated into phytomers. Length of each phytomer was measured and recorded. Phytomers were further divided into thirds. All comparable pieces (that is, same phytomers and same third [distal, middle, or proximal]) from plants collected from each experimental unit were combined, dried at about $60^{\circ} \mathrm{C}$, and ground with a Wiley mill to pass a $2-\mathrm{mm}$ screen. Nitrate was extracted and analyzed with a nitrate electrode as in the 20 -stalk experiment.

Data were subjected to analysis of variance within experiments using the MIXED procedure in SAS (Littell et al., 1996). Classification variables were block, rotation, $N$ rate, hybrid (in the irrigated study), phytomer, and segment. The block effect and all interactions with block were considered random in the analysis. When sources of variation were declared significant by analysis of variance $(\alpha=0.05)$, the $t$ test was used to separate means. When appropriate, single degreeof-freedom contrasts were employed to dissect significant treatment and interaction effects.

\section{RESULTS AND DISCUSSION}

\section{0-Stalk Experiment}

The corn stalk is composed of a number of tissues, but the two most noticeable on initial inspection are nodes and internodes. Since these tissues have different structure, appearance, and function, it is logical to assume that nitrate concentration might differ as well. Protocol for the stalk nitrate test states that stalk tissue from 15 to $35 \mathrm{~cm}$ above the ground be collected for analysis. This $20-\mathrm{cm}$ sample may be composed of a range of relative proportions of node and internode tissue, from all internode to several nodes and all or portions of several internodes. Analysis of data from nodes and internodes from the four phytomers analyzed in the 20stalk experiment was used to test the assumption that node and internode tissue differ in nitrate concentration and to determine the effect sample composition (fraction of node and internode tissue) has on estimated nitrate concentration.

All stalks collected for this study had at least four phytomers between the soil and the ear node, but some had as many as seven. To compare tissue with similar function and position, we processed only the phytomers immediately above the soil and below the ear and labeled them by position relative to the soil and ear, not with respect to their order of initiation. That is, we analyzed the two phytomers immediately above the soil and designated them $\mathrm{S}+1$ and $\mathrm{S}+2$. In addition, we analyzed the two phytomers immediately below the ear, $\mathrm{E}-1$ and $\mathrm{E}-2$. Zero to three phytomers between these phytomers were not analyzed.

Phytomers differed greatly in $\mathrm{NO}_{3}-\mathrm{N}$ concentration, decreasing from the soil $\left(\mathrm{S}+1 ; 4590 \mathrm{mg} \mathrm{NO}_{3}-\mathrm{N} \mathrm{kg}^{-1}\right)$ to the ear $\left(\mathrm{E}-1 ; 134 \mathrm{mg} \mathrm{NO}_{3}-\mathrm{N} \mathrm{kg}^{-1}\right.$; Table 1). Although both linear and quadratic components of the relationship between phytomer and $\mathrm{NO}_{3}-\mathrm{N}$ concentration were significant $(P<0.0001)$, the linear component was the stronger $\left(F_{\text {linear }}=981\right.$ vs. $\left.F_{\text {quadratic }}=27\right)$. The large discontinuity between $\mathrm{E}-2$ and $\mathrm{S}+2$ occurred because the four phytomers did not represent continuous phytomers on all plants (as explained in the previous paragraph).

Segments also differed in $\mathrm{NO}_{3}-\mathrm{N}$ concentration (Table 1). Again both the linear and quadratic components of variation were significant, but the linear component dominated the relationship. We conducted single degreeof-freedom comparisons to determine if node tissue differed from internode tissue in $\mathrm{NO}_{3}-\mathrm{N}$ concentration. First we compared Segment 0 (the node) with Segment 1 (the segment immediately above the node). These tissues did not differ $(P>F=0.94$; Table 1$)$. Second, we compared Segment 0 to the average $\mathrm{NO}_{3}-\mathrm{N}$ concentration in all internode tissue (Segments 1-5). Again, this contrast was not significant $(P>F=0.63)$. Lastly, we compared $\mathrm{NO}_{3}-\mathrm{N}$ concentration among the internode segments within a phytomer near the node (Segments 1 and 2) with those far from the node (Segments 4 and 5). These groups differed $(P>F<0.001)$ in $\mathrm{NO}_{3}-\mathrm{N}$ concentration. The $\mathrm{NO}_{3}-\mathrm{N}$ concentration patterns described above were similar for all phytomers as 
Table 1. Mean $\mathrm{NO}_{3}-\mathrm{N}$ concentration and analysis of variance of stalks from 20 -stalk experiment. Corn plants were grown with no irrigation near Lincoln, $\mathbf{N E}$.

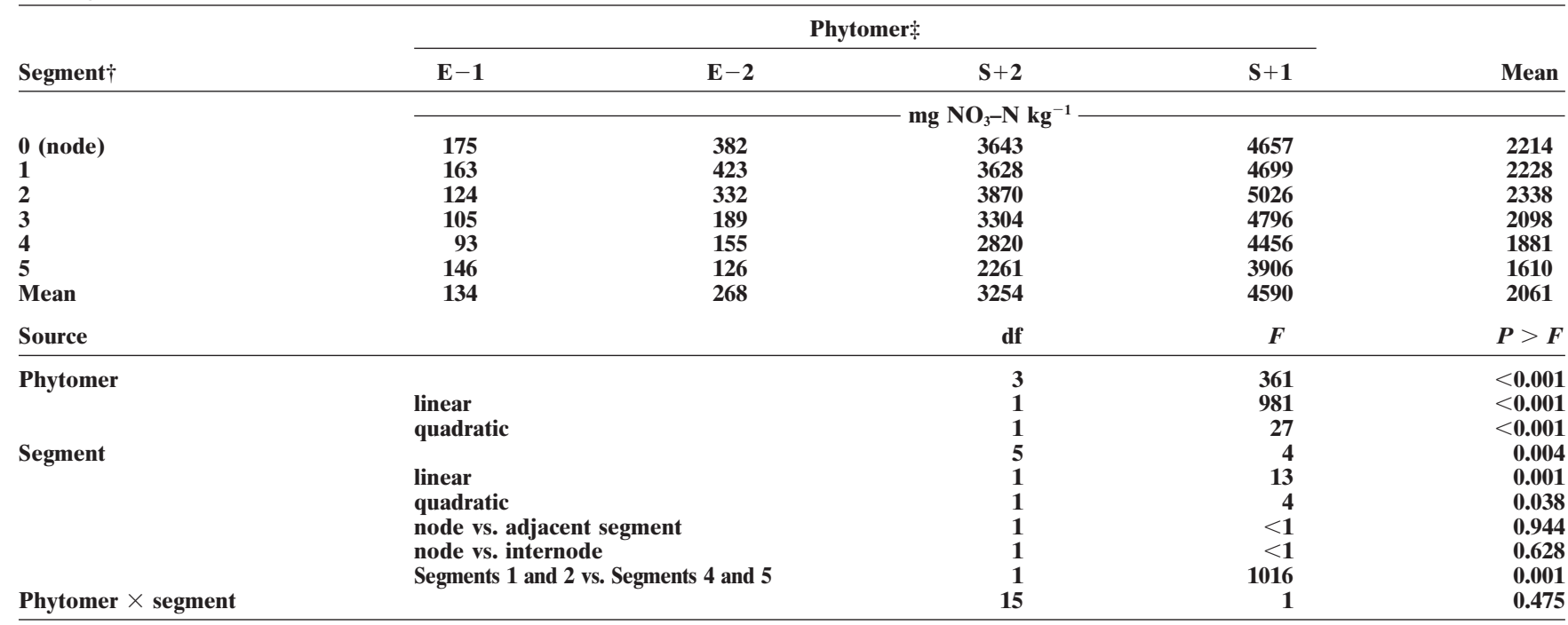

† Segment: 0, node; $1-5$, fifths of the internode above the node.

+ Phytomer: $\mathbf{E}-1$, first phytomer below the ear node; $\mathbf{E}-2$, second phytomer below the ear node; $\mathbf{S}+2$, second phytomer above the soil; $\mathrm{S}+1$, first phytomer above the soil.

indicated by the nonsignificant phytomer $\times$ segment interaction $(P>F=0.48$, Table 1$)$.

\section{Irrigated and Dryland Experiments}

More than $50 \%$ of the 480 plants sampled from the irrigated experiment had five phytomers between the soil and ear. At the dryland experiment nearly $75 \%$ of the 300 plants sampled had five phytomers between the soil and ear. For simplicity and ease of data analysis and presentation, only data from stalks with five phytomers were included in the data presented.

All first-order sources of variation, except hybrid, significantly affected the $\mathrm{NO}_{3}-\mathrm{N}$ concentration in the corn stalk from the soil surface to the ear node under irrigated conditions (Table 2). Although several interactions involving hybrid were significant sources of varia-

Table 2. Sources of variation, degrees of freedom, $\boldsymbol{F}$ value, and probability of a greater $\boldsymbol{F}$ for stalk $\mathrm{NO}_{3}-\mathrm{N}$ concentration determined on corn grown near Shelton, NE (irrigated experiment).

\begin{tabular}{|c|c|c|c|c|}
\hline & Numerator & Denominator & & \\
\hline Source & df & df & $F$ value & $\boldsymbol{P}>\boldsymbol{F}$ \\
\hline Crop sequence (Crop seq) & $\mathbf{1}$ & 8.9 & 7.00 & 0.027 \\
\hline Hybrid (Hyb) & $\mathbf{1}$ & 8.9 & 0.15 & 0.710 \\
\hline Nitrogen rate (N rate) & 2 & 20.3 & 106.75 & $<0.001$ \\
\hline Phytomer (Phyto) & 4 & 130.0 & 213.14 & $<\mathbf{0 . 0 0 1}$ \\
\hline Segment (Seg) $\dagger$ & 2 & 320.0 & 41.91 & $<0.001$ \\
\hline Crop seq $\times$ Hyb & 1 & 8.9 & 0.01 & 0.918 \\
\hline Crop seq $\times N$ rate & 2 & 20.3 & 3.75 & 0.041 \\
\hline Crop seq $\times$ Phyto & 4 & 130.0 & 16.94 & $<0.001$ \\
\hline Crop seq $\times$ Seg & 2 & 320.0 & 0.22 & 0.805 \\
\hline Hyb $\times N$ rate & 2 & 20.3 & 1.12 & 0.347 \\
\hline Hyb $\times$ Phyto & 4 & 130.0 & 14.31 & $<\mathbf{0 . 0 0 1}$ \\
\hline Hyb $\times$ Seg & 2 & 320.0 & 5.07 & 0.007 \\
\hline N rate $\times$ Phyto & 8 & 130.0 & 72.75 & $<0.001$ \\
\hline$N$ rate $\times$ Seg & 4 & 320.0 & 12.34 & $<0.001$ \\
\hline Phyto $\times$ Seg & 8 & 320.0 & 2.14 & 0.032 \\
\hline Crop seq $\times$ Hyb $\times N$ rate & 2 & 20.3 & 1.21 & 0.320 \\
\hline Crop seq $\times$ Hyb $\times$ Phyto & 4 & 130.0 & 1.02 & 0.717 \\
\hline Crop seq $\times$ Hyb $\times$ Seg & 2 & 320.0 & 0.78 & 0.462 \\
\hline Crop seq $\times$ N rate $\times$ Phyto & 8 & 130.0 & 5.66 & $<\mathbf{0 . 0 0 1}$ \\
\hline Crop seq $\times \mathbf{N}$ rate $\times$ Seg & 4 & 320.0 & 1.36 & 0.247 \\
\hline Crop seq $\times$ Phyto $\times$ Seg & 8 & 320.0 & 2.01 & 0.045 \\
\hline Hyb $\times N$ rate $\times$ Phyto & 8 & 130.0 & 3.40 & 0.001 \\
\hline Hyb $\times N$ rate $\times$ Seg & 4 & 320.0 & 1.70 & 0.151 \\
\hline N rate $\times$ Phyto $\times$ Seg & 16 & 320.0 & 2.97 & $<0.001$ \\
\hline Hyb $\times$ Phyto $\times$ Seg & 8 & 320.0 & 2.60 & 0.009 \\
\hline Crop seq $\times$ Hyb $\times$ N rate $\times$ Phyto & 8 & 130.0 & 1.31 & 0.350 \\
\hline Crop seq $\times$ Hyb $\times$ N rate $\times$ Seg & 4 & 320.0 & 0.22 & 0.926 \\
\hline Crop seq $\times$ N rate $\times$ Phyto $\times$ Seg & 16 & 320.0 & 1.11 & 0.348 \\
\hline Crop seq $\times$ Hyb $\times$ Phyto $\times$ Seg & 8 & 320.0 & 1.11 & 0.356 \\
\hline Hyb $\times$ N rate $\times$ Phyto $\times$ Seg & 16 & 320.0 & 1.52 & 0.090 \\
\hline Crop seq. $\times$ Hyb $\times$ N rate $\times$ Phyto $\times$ Seg & 16 & 320.0 & 0.44 & 0.972 \\
\hline
\end{tabular}

$\dagger$ Section of corn stalk, each section represents one-third of phytomer. 

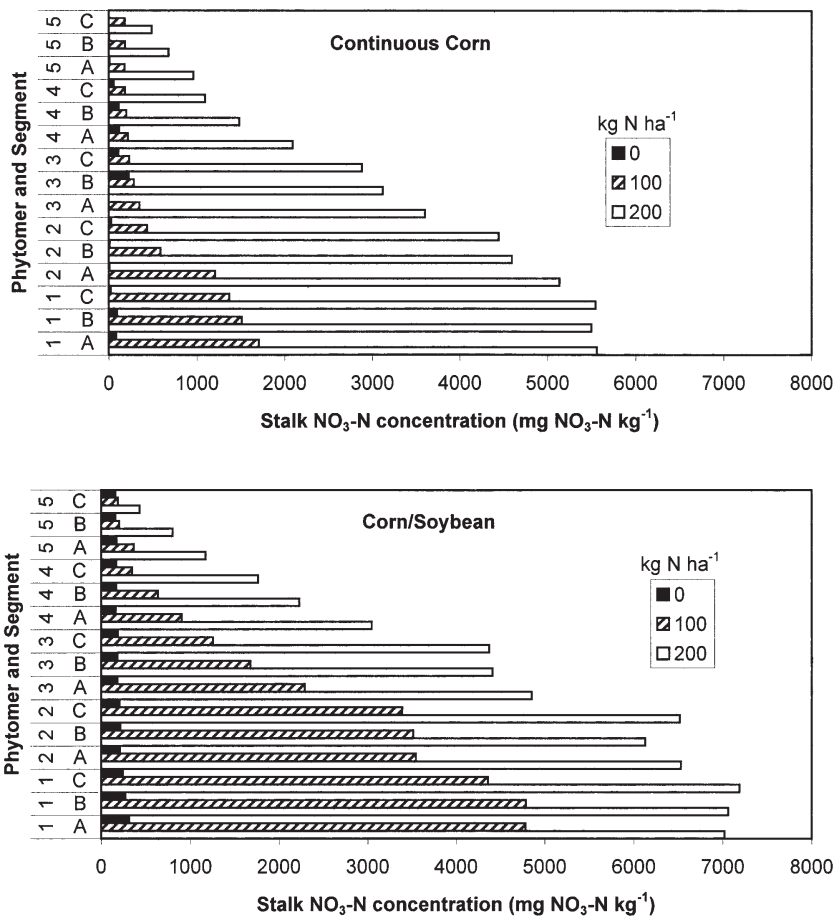

Fig. 1. Mean $\mathrm{NO}_{3}-\mathrm{N}$ concentration of stalk segments determined on corn (mean of two hybrids) grown near Shelton, NE (irrigated experiment). On the $y$ axis, digits designate phytomers $(1=$ nearest the soil; 5 = subtending the ear); letters designate segments of phytomers.

tion, all were caused by slight differences in slope of the linear association between factors and not the direction of the relationship (data not shown). Therefore, to simplify presentation of data, means over hybrids are reported in Fig. 1. Of the third-, fourth-, and fifth-order interactions, only crop sequence $\times \mathrm{N}$ rate $\times$ phytomer, crop sequence $\times$ phytomer $\times$ segment, hybrid $\times \mathrm{N}$ rate $\times$ phytomer, and $\mathrm{N}$ rate $\times$ phytomer $\times$ segment were significant sources of variation.

In the dryland experiment all sources of variation were significant except crop sequence, crop sequence $X$ $\mathrm{N}$ rate $\times$ segment, and the crop sequence $\times$ phytomer $\times$ segment interaction (Table 3). Generally, sources of variation involving crop sequence were of less impor-
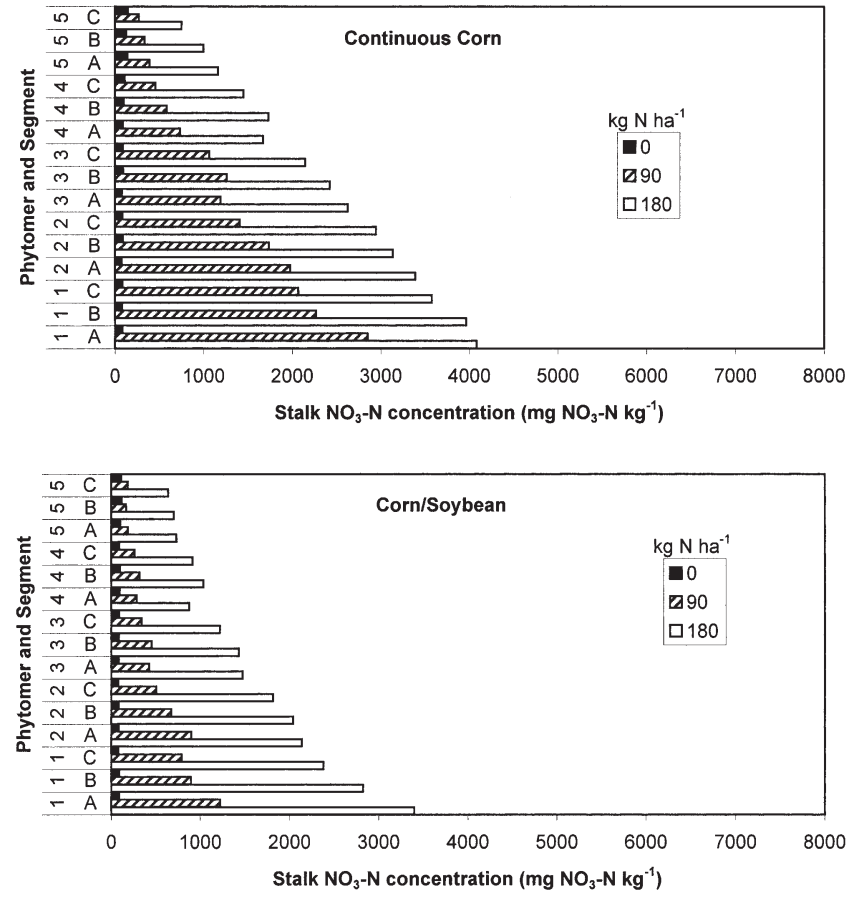

Fig. 2. Mean $\mathrm{NO}_{3}-\mathrm{N}$ concentration of stalk segments determined on corn (Pioneer Brand hybrid 3162) grown near Mead, NE (dryland experiment). On the $y$ axis, digits designate phytomers $(1=$ nearest the soil; 5 = subtending the ear); letters designate segments of phytomers.

tance, as indicated by comparatively lesser $F$ values, in determining $\mathrm{NO}_{3}-\mathrm{N}$ concentration of the corn stalk than other management practices.

In both the irrigated and dryland experiments, stalk $\mathrm{NO}_{3}-\mathrm{N}$ concentration increased linearly as applied $\mathrm{N}$ increased $(P<0.001)$. Consistent with the observation in the 20-stalk experiment, stalk $\mathrm{NO}_{3}-\mathrm{N}$ concentration decreased linearly for both phytomers $(P<0.001)$ and segments $(P<0.001)$ as their position neared the ear.

Comparing results between the irrigated and dryland experiment, it is apparent that more $\mathrm{N}$ was available to plants late in the season in the irrigated experiment (Fig. 1) than the dryland experiment (Fig. 2). Mean stalk nitrate concentration was $1729 \mathrm{mg} \mathrm{NO}-\mathrm{N} \mathrm{kg}^{-1}$ in

Table 3. Sources of variation, degrees of freedom, $F$ value, and probability of a greater $F$ for stalk $\mathrm{NO}_{3}-\mathrm{N}$ concentration determined on corn grown near Mead, NE (dryland experiment).

\begin{tabular}{|c|c|c|c|c|}
\hline & Numerator & Denominator & & \\
\hline Source & df & df & $F$ value & $\boldsymbol{P}>\boldsymbol{F}$ \\
\hline Crop sequence (Crop seq) & 1 & 1.2 & 7.13 & 0.190 \\
\hline Nitrogen rate ( $\mathrm{N}$ rate) & 2 & 17.5 & 85.34 & $<0.001$ \\
\hline Phytomer (Phyt) & 4 & 96.2 & 93.45 & $<0.001$ \\
\hline Segment $($ Seg $) \dagger$ & 2 & 230.0 & 99.00 & $<0.001$ \\
\hline Crop seq $\times$ N rate & 2 & 17.5 & 4.67 & 0.024 \\
\hline Crop seq $\times$ Phyt & 4 & 96.2 & 6.44 & $<\mathbf{0 . 0 0 1}$ \\
\hline Crop seq $\times$ Seg & 2 & 230.0 & 3.83 & 0.023 \\
\hline$N$ rate $\times$ Phyto & 8 & 96.2 & 31.22 & $<\mathbf{0 . 0 0 1}$ \\
\hline $\mathrm{N}$ rate $\times$ Seg & 4 & 230.0 & 28.94 & $<\mathbf{0 . 0 0 1}$ \\
\hline Phyto $\times$ Seg & 8 & 230.0 & 11.30 & $<0.001$ \\
\hline Crop seq $\times N$ rate $\times$ Phyto & 8 & 96.2 & 2.37 & 0.023 \\
\hline Crop seq $\times N$ rate $\times$ Seg & 4 & 230.0 & 1.75 & 0.140 \\
\hline Crop seq $\times$ Phyto $\times$ Seg & 8 & 230.0 & 0.85 & 0.564 \\
\hline N rate $\times$ Phyto $\times$ Seg & 16 & 230.0 & 3.97 & $<\mathbf{0 . 0 0 1}$ \\
\hline Crop seq $\times$ N rate $\times$ Phyto $\times$ Seg & 16 & 230.0 & 2.27 & 0.004 \\
\hline
\end{tabular}

$\dagger$ Section of corn stalk, each section represents one-third of phytomer. 
the irrigated experiment compared with $986 \mathrm{mg} \mathrm{NO}_{3}-\mathrm{N}$ $\mathrm{kg}^{-1}$ for the dryland experiment. In the irrigated experiment stalk $\mathrm{NO}_{3}-\mathrm{N}$ concentration was greater in the corn grown in rotation with soybean $\left(2194 \mathrm{mg} \mathrm{NO}_{3}-\mathrm{N} \mathrm{kg}^{-1}\right)$ than the continuous corn (1264 $\left.\mathrm{mg} \mathrm{NO}_{3}-\mathrm{N} \mathrm{kg}^{-1}\right)$. However, in the dryland experiment, the opposite was true: corn-soybean rotation, $725 \mathrm{mg} \mathrm{NO}_{3}-\mathrm{N} \mathrm{kg}^{-1}$; continuous corn, $1247 \mathrm{mg} \mathrm{NO} \mathrm{NO}_{3}-\mathrm{N} \mathrm{kg}^{-1}$. The contrasting response from the dryland and irrigated experiments may appear illogical since more $\mathrm{N}$ would be taken up by the greater production of both stover and grain under irrigation. In addition, the greater yield with irrigation would also result in greater $\mathrm{N}$ removal in the grain. Fertilizer application rates differed slightly between the irrigated and dryland experiments. Nitrogen fertilizer was applied to both corn and soybean in the irrigated experiment, but only to the corn in the dryland experiment. As a result, during a 2-yr period (one cycle of the corn-soybean rotation) the greatest $\mathrm{N}$-rate treatment with continuous corn in the dryland experiment received $360 \mathrm{~kg} \mathrm{~N} \mathrm{ha}^{-1}$ while the plots used for the rotated corn received only $180 \mathrm{~kg} \mathrm{~N} \mathrm{ha}{ }^{-1}$. In the greatest $\mathrm{N}$-rate treatment in the irrigated experiment, both the continuous corn and rotated corn treatments received $400 \mathrm{~kg} \mathrm{~N} \mathrm{ha}^{-1}$. The difference in procedures likely explains part of the apparent dichotomy in results seen in Fig. 1 and 2. Soil was generally much drier during grain filling for the dryland experiment than the irrigated experiment. With drier soil, rate of mineralization would be reduced and less $\mathrm{N}$ was available to the dryland crop (Varvel and Peterson, 1990). Lastly, irrigation water used for the irrigated study contained $30 \mathrm{mg} \mathrm{NO}-\mathrm{N} \mathrm{L}^{-1}$, resulting in about $60 \mathrm{~kg} \mathrm{~N} \mathrm{ha}^{-1}$ applied to the experiment over the course of the irrigation season, in increments of about $10 \mathrm{~kg}$ $\mathrm{N} \mathrm{ha}^{-1}$ from stages V10 through R5 (Ritchie et al., 1986).

Phytomers and segments, and their interactions with other classification factors, were significant sources of variation for $\mathrm{NO}_{3}-\mathrm{N}$ concentration under both dryland and irrigated conditions (Tables 2 and 3 ). Both fractions of the stalk showed a strong linear $(P<0.001)$ acropetal (from base to apex) decline in $\mathrm{NO}_{3}-\mathrm{N}$ concentration. In all cases, interactions were related to the magnitude of the linear decline in $\mathrm{NO}_{3}-\mathrm{N}$ concentration, not the sign or existence of the relationship.

The primary purposes of this work was to determine the impact of collecting and analyzing stalk segments for $\mathrm{NO}_{3}-\mathrm{N}$ that differed from the one defined in the original report on the stalk nitrate test by Binford et al. (1990). As discussed above, stalks were divided into phytomers and segments within phytomers before analysis for $\mathrm{NO}_{3}-\mathrm{N}$. In addition, the length of each phytomer was recorded before it was divided. These data allow calculation of the $\mathrm{NO}_{3}-\mathrm{N}$ concentration of a $20-\mathrm{cm}$ portion of stalk normally used for the stalk nitrate test, based on weighted means, and comparison of that concentration to other values. The first concern is the impact of tissue (node and internode tissue) composition of the sample. The second concern is the impact of error in sample collection. That is, what is the impact of collecting a sample lower or higher on the stalk than specified by Binford et al. (1990). Lastly, for several
Table 4. Mean $\mathrm{NO}_{3}-\mathrm{N}$ concentration of stalk segments from $\mathbf{1 0}$ to 30,15 to 35 , and 20 to $40 \mathrm{~cm}$ above the soil from the irrigated and dryland experiments.

\begin{tabular}{|c|c|c|}
\hline \multirow[b]{2}{*}{ Segment $\dagger$} & \multicolumn{2}{|c|}{ Experiment } \\
\hline & Irrigated & Dryland \\
\hline & 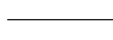 & \\
\hline $10-30 \mathrm{~cm}$ & 2556 & 1151 \\
\hline $15-35 \mathrm{~cm}$ & 2273 & 993 \\
\hline $20-40 \mathrm{~cm}$ & 2015 & 858 \\
\hline SE & 216 & 84 \\
\hline
\end{tabular}

$\dagger 10$ to $30 \mathrm{~cm}$ is $5 \mathrm{~cm}$ nearer the soil than the segment specified for the end-of-season stalk nitrate test $(15-35 \mathrm{~cm}$; Binford et al., 1990); 20 to $40 \mathrm{~cm}$ is $5 \mathrm{~cm}$ farther from the soil than specified.

reasons (Wilhelm et al., 2001), we have found collecting samples composed of one phytomer from the base of the stalk more convenient than following the procedures outlined by Binford et al. (1990). The reasons include our concern about relative tissue component of the sample and ease of sample handling. Frequently we collect stalk nitrate samples in conjunction with plant dry matter sampling. Since the plants are already cut at the soil surface, collecting the basal phytomer is easier than cutting the stalk at 15 and $35 \mathrm{~cm}$ above the soil line and risking misplacing or mislabeling the detached 0 - to $15-\mathrm{cm}$ segment of stalk.

Data from the 20-stalk experiment refute our assumption that node and internode tissue would have different $\mathrm{NO}_{3}-\mathrm{N}$ concentrations (Table 1 ). Node tissue averaged $2214 \mathrm{mg} \mathrm{NO}-\mathrm{N} \mathrm{kg}^{-1}$ and internode tissue $2031 \mathrm{mg}$ $\mathrm{NO}_{3}-\mathrm{N} \mathrm{kg}^{-1}$ (Table 1). The average internode $\mathrm{NO}_{3}-\mathrm{N}$ concentration exaggerates the true difference because of the linear decline in $\mathrm{NO}_{3}-\mathrm{N}$ concentration along the internode. Mean $\mathrm{NO}_{3}-\mathrm{N}$ concentration of the node was $2214 \mathrm{mg} \mathrm{NO}-\mathrm{N} \mathrm{kg}^{-1}$; mean concentration for the segment of internode immediately above the node was $2228 \mathrm{mg} \mathrm{NO}{ }_{3}-\mathrm{N} \mathrm{kg}^{-1}$ (Table 1).

Using data on $\mathrm{NO}_{3}-\mathrm{N}$ concentration and length of each stalk segment from the irrigated and dryland experiments, we calculated the $\mathrm{NO}_{3}-\mathrm{N}$ concentration for three $20-\mathrm{cm}$ segments of each sample; 10 to 30,15 to 35 , and 20 to $40 \mathrm{~cm}$ above the soil. These represent a sample collected $5 \mathrm{~cm}$ lower on the stalk than specified by Binford et al. (1990), as specified in the stalk nitrate test, and $5 \mathrm{~cm}$ above the specified segment, respectively. The two samples offset $5 \mathrm{~cm}$ from the specified segment represent a sampling difference of $25 \%$ of the $20-\mathrm{cm}$ specified segment length. In both experiments shifting the sampled segment of stalk significantly affected the reported $\mathrm{NO}_{3}-\mathrm{N}$ concentration (Table 4). The $\mathrm{NO}_{3}-\mathrm{N}$ concentration estimated from the segments collected $5 \mathrm{~cm}$ nearer the soil or $5 \mathrm{~cm}$ nearer the ear than specified in the test, resulted in only a 10 to $15 \%$ difference in $\mathrm{NO}_{3}-\mathrm{N}$ concentration. Although this error would change the assessment of $\mathrm{N}$ availability for samples with $\mathrm{NO}_{3}-\mathrm{N}$ concentrations near the critical values, 700 and $2000 \mathrm{mg}$ $\mathrm{NO}_{3}-\mathrm{N} \mathrm{kg}^{-1}$, the general outcome of the test would not be changed because of the extremely wide range of $\mathrm{NO}_{3}-\mathrm{N}$ concentrations observed in field samples and the somewhat nonspecific nature of the critical value (Binford et al., 1990; 1992). Plus or minus $15 \%$ of the critical values, 640 to 860 and 1700 to $2300 \mathrm{mg} \mathrm{NO}-\mathrm{N}$ 
Table 5. Mean $\mathrm{NO}_{3}-\mathrm{N}$ concentration of stalk segments from 15 to $35 \mathrm{~cm}$ above the soil and the first phytomer above the soil from the irrigated and dryland experiments.

\begin{tabular}{|c|c|c|}
\hline \multirow[b]{2}{*}{ Segment } & \multicolumn{2}{|c|}{ Experiment } \\
\hline & Irrigated & Dryland \\
\hline \multirow{4}{*}{$\begin{array}{l}15-35 \mathrm{~cm} \\
\text { First phytomer } \\
\text { SE }\end{array}$} & & 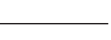 \\
\hline & 2273 & 993 \\
\hline & 3193 & 1714 \\
\hline & 362 & 112 \\
\hline
\end{tabular}

$\mathrm{kg}^{-1}$, respectively, could be used as critical ranges to define $\mathrm{N}$-limiting, $\mathrm{N}$-adequate, and $\mathrm{N}$-excessive conditions. Since the test is more qualitative than quantitative, these relatively small differences will not greatly affect recommendations. This is especially true when one recognizes that $\mathrm{NO}_{3}-\mathrm{N}$ concentrations can range more than three orders of magnitude for reasonable production practices in use for corn production in the Corn Belt.

Lastly, we assessed the impact of sampling one phytomer, immediately above the soil surface, on stalk nitrate test recommendations. Measured $\mathrm{NO}_{3}-\mathrm{N}$ concentrations differed, in both the irrigated and dryland experiments, for the $15-$ to $35-\mathrm{cm}$ length specified by Binford et al. (1990) and the phytomer nearest the soil (Table 5). The difference in $\mathrm{NO}_{3}-\mathrm{N}$ concentrations between the two methods is great enough that the critical values of 700 and $2000 \mathrm{mg} \mathrm{NO}{ }_{3}-\mathrm{N} \mathrm{kg}^{-1}$ (Binford et al., 1990) should be adjusted upward. Regressing sample $\mathrm{NO}_{3}-\mathrm{N}$ concentrations from the standard sampling procedure against the concentrations for the first phytomer resulted in slopes of 1.57 and 1.21 for the dryland and irrigated studies, respectively. As suggested by Wilhelm et al. (2001), an increase in critical values of 35 to $40 \%$ would be appropriate when sampling lower parts of the stalk. This adjustment would result in critical values of 950 to 1000 and 2700 to $3000 \mathrm{mg} \mathrm{NO}-\mathrm{N} \mathrm{kg}^{-1}$ for the break points between $\mathrm{N}$-limited yield and adequate $\mathrm{N}$ for optimum yield and adequate $\mathrm{N}$ for optimum yield and $\mathrm{N}$ in excess of that needed for optimum yield.

In summary, the end-of-season stalk nitrate test is foremost a robust, qualitative diagnostic tool to determine if yield-limiting, adequate, or excessive amounts of $\mathrm{N}$ were available to the corn crop during grain fill. To be useful, critical values must be defined. However, as Binford et al. (1992) suggested, it is futile to attempt to define critcal values too precisely. As long as samples are collected from section of stalk similar to that described by Binford et al. $(1990,1992)$, critical values near those they suggested serve to differentiate conditions of yield-limiting, adequate, and excessive $\mathrm{N}$ availability. Truly yield-limiting conditions usually result in stalk $\mathrm{NO}_{3}-\mathrm{N}$ concontrations that are far less than $700 \mathrm{mg}$ $\mathrm{NO}_{3}-\mathrm{N} \mathrm{kg}^{-1}$. Likewise, excessive $\mathrm{N}$ applications result in stalk $\mathrm{NO}_{3}-\mathrm{N}$ concentrations much greater than $2000 \mathrm{mg}$ $\mathrm{NO}_{3}-\mathrm{N} \mathrm{kg}^{-1}$.

\section{REFERENCES}

Binford, G.D., A.M. Blackmer, and N.M. El-Hout. 1990. Tissue test for excess nitrogen during corn production. Agron. J. 82:124-129.

Binford, G.D., A.M. Blackmer, and B.G. Meese. 1992. Optimal concentration of nitrate in cornstalks at maturity. Agron. J. 84:881-887.

Littell, R.C., G.A. Milliken, W.W. Stroup, and R.D. Wolfinger. 1996. SAS system for mixed models. SAS Inst., Cary, NC.

Ritchie, S.W., J.J. Hanway, and G.O. Benson. 1986. How a corn plant develops. Spec. Rep. 48. Iowa State Univ. of Science and Technol.-Coop. Ext. Service, Ames, IA.

Varvel, G.E., and T.A. Peterson. 1990. Nitrogen fertilizer recovery by corn in monoculture and rotation systems. Agron. J. 82:935-938.

Varvel, G.E., J.S. Schepers, and D.D. Francis. 1997. Chlorophyll meter and stalk nitrate techniques as complimentary indices of residual nitrogen. J. Prod. Agric. 10:147-151.

Wilhelm, W.W., S.L. Arnold, and J.S. Schepers. 2000. Nitrate electrode analysis of corn stalk samples. Agron. J. 92:186-189.

Wilhelm, W.W., G.E. Varvel, and J.S. Schepers. 2001. Corn stalk nitrate concentration profile: Implications for the end-of-season stalk nitrate test. p. 708-709. In W.J. Horst et al. (ed.) Plant nutrition: Food security and sustainability of agro-ecosystems through basic and applied research. Proc. of the Int. Plant Nutrition Colloquium. Kluwer Academic Publ., Dordrecht, the Netherlands. 